\title{
Entrepreneurial orientation and product innovation. The moderating role of family involvement in management.
}

\author{
Taras Fredyna $^{\mathrm{a}^{*}}$, Daniel Ruíz-Palomo ${ }^{\mathrm{b}}$, Julio Dieguez ${ }^{\mathrm{b}}$ \\ ${ }^{\mathrm{a}}$ Graduated in Management and Business and Law, University of Málaga (Spain) \\ ${ }^{b}$ Department of Accounting and Finance, University of Málaga (Spain)
}

Received 12 December 2018; accepted 19 December 2019

\section{JEL}

CLASSIFICATION

L26, 032

KEYWORDS

Family

involvement;

Entrepreneurial

Orientation;

Product Innovation;

Radical Innovation;

Incremental

Innovation

\section{CÓDIGOS JEL}

L26, 032

\section{PALABRAS CLAVE}

Implicación

familiar;

Orientación

Emprendedora;

Innovación en

Productos;

Innovación Radical;

Innovación

Incremental

\begin{abstract}
In this current research it has been examined, firstly, the Entrepreneurial orientation in relation with Product innovation, Incremental innovation and Radical innovation, and, secondly, the moderating effect of Family involvement in the management of companies in the relationship between Entrepreneurial orientation and Product innovation, Incremental innovation and Radical innovation. Using a sample of 634 Spanish family firms, the results found conclude that the Entrepreneurial orientation has a positive effect on Product innovation, Incremental innovation and Radical innovation, and moreover, they reveal that the Family involvement in the management of companies has a moderating effect on these relations, witnessing that family firms with higher scale of Family involvement in the management of the companies reduces the effect of Entrepreneurial orientation on Product innovation, Incremental innovation and finally, Radical innovation.
\end{abstract}

Copyright 2019: Taras Fredyna, Daniel Ruíz-Palomo, Julio Dieguez.

European Journal of Family Business is an open access journal published in Malaga by UMA Editorial. ISSN 2444-8788 ISSN-e 2444-877X This work is licensed under a Creative Commons Atribution-NonCommercial-ShareAlike 4.0 International License (CC BY-NC-SA 4.0). 


\section{Introduction}

The Entrepreneurial Orientation, it is understood as a strategic process whereby companies can identify new opportunities and carry out entrepreneurial actions to later take advantage of them (Dess and Lumpkin, 2005), is an important figure in the field of entrepreneurship, due to its Influence on the results, value, and growth of a company, it has been the subject of many studies in recent years. Most of these researches are based on a series of conceptual bases that, constructed on the definition of Miller's Entrepreneurial orientation (1983), were established by Lumpkin and Dess (1996), which are as follows:

- Entrepreneurial orientation includes five dimensions, which are innovation, assumption of risk, proactivity, competitive aggressiveness and autonomy.

- The dimensions of the entrepreneurial orientation are independent but related.

- The direct relationship between the entrepreneurial orientation and the performance may differ because of others mediating or moderating variables.

In the field of entrepreneurship research, there are several studies that have analysed the different relationships of it with other variables, such as business result (Smart and Conant, 1994; George, Wood and Khan, 2001; Rauch et al., 2009), or the growth of a company (Wiklund and Shepherd, 2005; Moreno and Casillas, 2008; Casilla and Moreno, 2010). Likewise, it has been studied the effect and importance of different variables on entrepreneurial orientation, such as the organizational structure (Covin and Slevin, 1988; Green, Covin and Slevin, 2008), degree of dynamism in the sector (Lumpkin and Dess, 2001; Wiklund and Shepherd, 2005), technological intensity in industry (Covin and Slevin, 1989), social capital (Stam and Elfring, 2008), as well as innovation (Elenurm, Ennulo and Laar, 2007; Rauch et al., 2009; Fernández-Mesa et al., 2012), highlighting not only the positive association between entrepreneurship and innovation (Fernández-Mesa et al., 2012), but also its importance on business performance (Newey and Zahra, 2009; Baker and Sinkula, 2009).

Accordingly, investigations indicate that enterprising companies, unlike other conservative companies, innovate more regularly and frequently, while taking risks, which are considered in their product market as strategies (Miller and Friesen, 1982). The concept of Innovation can be understood from different points of view; hence, a company can innovate by: (i) changes in its working methods; (ii) in the use of productive factors or (iii) in the ways of carrying out production. Following the Oslo
Manual (2005), there are four types of innovations that cover a wide range of changes which can take place in the activities of a company: (i) Product innovation, (ii) Process innovation, (iii) Organizational innovation and (iv) Marketing innovation.

Bearing in mind the diverse types of innovation described above, most of the researches, as well as in this article, are about Technological Innovation (a concept closely related to Product innovation, according to the Oslo Manual (2005), which Souitaris (2003) justifies as any change in things, products or services offered by an organization (Product innovation) and any change in the way these are created and delivered (Process innovation). The interest in this kind of innovation is mainly due to its major influence on industrial competitiveness and national development since it is an important determinant of sustained performance (Blundell et al., 1999). Additionally, we can differentiate two other forms of innovation: Radical innovation and Incremental innovation (Clausen and Pohjola, 2013). Radical innovations are defined as innovations in products which are new and unknown to the market in which the company operates; while incremental innovations are new product innovations to the company but, not new to the market.

Literature reveals that several researches support the existence of a positive relationship between entrepreneurial orientation and innovation (Nasution et al., 2010). In the same way, there are other studies, which confirm a positive influence of entrepreneurial orientation on product innovation (Boso et al., 2013; Avlonitisa and Salavoub, 2007; Zhou et al., 2005) and on radical innovation (Zhou, Yim, and Tse, 2005). However, to the best of our knowledge, entrepreneurial orientation literature has not analysed the relation mentioned above, distinguishing between radical and incremental innovation. In order to attempts to fill this gap, this study analyses not only the relationship between entrepreneurial orientation and product innovation, but also distinguishes between radical and incremental innovation. We consider, in accordance with Sorescu and Spanjol (2008), that the influence of entrepreneurial orientation on such type of product innovation may differs due to the different levels of efforts which are needed to its implementation (risk-taking, investments or organizational and management capacities) and its impacts in the firm performance (growth, ROA,...).

Furthermore, the context of Family Firm, which plays a very important role in the world economy (Aranoff and Ward, 1995; La Porta et al., 1999; Neubauer and Lank, 1998), presents a special interest in the literature of entrepreneurial orientation (Zahra et al., 2004; Steier, 2007; 
Steier, 2009) and innovation (Craig and Moores, 2006; Pittino and Visintin, 2009).

Thus, within the field of entrepreneurship research, family firms present an unique and exceptional context. The singularity of family firms is manifested through its structure of resources and capacities (Sirmon and Hitt, 2003; Dyer 2006), which can ease or restrict its entrepreneurial activities (Habbershon, Williams and MacMillan, 2003; Howorth, 2007; Nordqvist, Habbershon and Melin, 2008). The studies carried out in this field show that there is a dual relationship between family firms and the entrepreneurial orientation (Nordqvist, Habbershon, and Melin, 2008). On the one hand, certain characteristics of family firms help to develop its entrepreneurship (Aldrich and Cliff, 2003), such as its culture (Hall, Melin, and Nordqvist, 2001; Nordqvist et al., 2008; Zahra et al., 2004) or its centralized structure, which also influences the proactive and innovative conduct of the company (Salvato, 2004). However, there are other factors of these types of companies, which have a reducing effect on its entrepreneurship, such as their greater resistance to change or their aversion to risk (Naldi et al., 2007; Zahra, 2005). Such duality, as well as its uniqueness, makes the relationships between entrepreneurial orientation and family firms may become an interesting field of study.

Likewise, in the field of Innovation, there is also much interest in family firms, as well as its relationship with innovation. Traditionally, family firms are considered more conservative (Sharma, Chrisman, and Chua, 1997), less keen to change (Kets de Vries, 1993; Ward, 1997), more risk-averse (Naldi et al., 2007), and with greater difficulty to get access to capital markets (Kets de Vries, 1993), therefore, some studies indicate that the relationship between family involvement in the company and innovation is negative (Chen and Hsu, 2009). Nevertheless, family firms should have incentives to innovate, since that innovation creates wealth and opens up new business opportunities. Hence, it is coherent with their survival instinct and concern for their long-term continuity (Sirmon et al., 2008). In this sense, other studies confirm the existence of a positive relationship between the family involvement in the company and innovation (Zahra 2005; Margaret, 2008; Casillas and Moreno, 2010). In addition, family involvement in a company influences the process of making strategic decisions (Miller, Le BretonMiller, and Lester, 2011), and therefore, has an impact on decisions related to the innovation. Furthermore, studies on innovation in family firms are usually focused on product (De Massis et al., 2013), process (Classen et al., 2014) or organizational (Madrid-Guijarro, García and Van Auken, 2009) innovation.
Despite the importance of family management to act as a driver of the willingness and ability to impact on product innovation, as far as we know, no one has empirically investigated the interaction effect of family management and entrepreneurial innovation on product innovation. Thus, we bridge an important gap in literature studying the moderating effect of family management in the entrepreneurial orientation-product innovation interplay. In addition, we have not only analysed the moderating effect in the mentioned relationship, but also we distinguish between radical and incremental innovation.

Therefore, we propose the following research questions: Has entrepreneurial orientation a positive impact on product innovation? Does this relationship differ if we distinguish between radical and incremental innovation? And, finally, are these relationships affected by family management?

Bearing in mind the above gaps identified and research questions, the aim of this article is to study the influence of entrepreneurial orientation on product innovation, distinguishing between incremental and radical innovation. Furthermore, this work aims to analyse the moderating effect of Family Involvement in the management of the company in the relationship between Entrepreneurial Orientation and Product Innovation. To this end, we integrate our arguments using Resource Based View as the theoretical background of reference.

For those purposes, an empirical study has been developed through a regression model, using data obtained from a survey, which comprises a total of 634 business managers located in the Region of Murcia (Spain).

The obtained results indicate that family management decreases the positive effect of entrepreneurial orientation on product innovation, radical innovation and incremental innovation. These results contribute to the family business literature in several ways. Firstly, whereas previous studies have mainly analysed the relationship between entrepreneurial orientation and product innovation, we further examine this relationship distinguishing between radical innovation and incremental innovation. In this way, we develop a more fine-grained understanding of entrepreneurial orientation-product innovation relationship. Secondly, we also study the moderating effect of family management in the relationship between entrepreneurial orientation and product innovation, radical innovation and incremental innovation, showing that family management has a negative moderating effect. Thus, this paper contributes to an enhanced understanding of the moderating role of family management in the obtaining of product innovation, giving a more nuanced picture of 
entrepreneurial orientation-product innovation relationship.

The current study is divided into several sections. The next section offers the theoretical bases of the entrepreneurial orientation, product innovation and family concepts, as well as the existing relationships between them will be explained. Then, in section three the Methodology used will be described, showing the sample, the data and main the variables, followed by the presentation of the findings obtained. Finally, in section forth the main findings of the study will be exposed and commented.

\section{Theorical framework an Hypothesis}

\section{The Entrepreneurial Orientation and Product Innovation}

Miller (1983, pp.771) has been the pioneer defining the concept of entrepreneurial orientation, according to which entrepreneurial companies are "those that are geared towards innovation in the product - market field by carrying out risky initiatives, and which are the first to develop innovations in a proactive way in an attempt to defeat their competitors". Miller not only defined the concept of entrepreneurial orientation but also established three distinguishing dimensions of it, such as (i) innovativeness, (ii) risk-taking (iii) proactiveness. Later, Lumpkin and Dess (1996) suggested two more dimensions besides the three previous ones proposed by Miller (1983), such as (iv) competitive aggressiveness and ( $\mathrm{v}$ ) autonomy, establishing a total of five dimensions, but this conceptualization has not been widely adopted (Wales et al.. 2013), and it has been argued that the original three-dimension of entrepreneurial orientation is best from a conceptual point of view (George and Marino, 2011). Therefore, focused on Miller's (1983) original conceptualization, researchers agree on the three dimensions of entrepreneurial orientation (Covin and Wales 2018; Rauch et al. 2009; Wales et al. 2013): innovation, risk-taking, and proactiveness. Moreover, Covin and Slevin (1989, pp.79) have identified these three dimensions as "a basic, unidimensional strategic orientation" which implies that only companies that exhibit high levels of all three dimension should be regarded as entrepreneurial. Furthermore, these three characteristics were positioned by Miller (1983) as the heart of entrepreneurial orientation and are often combined to create a higher-order indicator of firm-level entrepreneurship (Rauch et al., 2009). Therefore, we defined entrepreneurial orientation as a firm-level construct of these three dimensions where innovativeness, risktaking, and proactiveness, as it has been used in literature (Wiklund and Shepherd, 2005; Rauch et al., 2009; Wales et al., 2013; Wales et al., 2018).

Thus, a dimension of innovativeness is understood, according to Lumpkin and Dess (1996, pp. 142), as "a firm's tendency to engage in and support new ideas, novelty, experimentation, and creative processes that may result in new products, services, or technological processes". As regards the dimension of proactiveness, according to Hughes and Morgan (2007), it represents a future perspective where companies try to develop new products or improvements in them, anticipating the changes and opportunities that appear in the business setting, promoting changes in current tactics and detecting future market trends. And also, by its own, the risk-taking dimension is understood as "the degree to which managers are willing to make large and risky resource commitments - i.e., those which have a reasonable chance of costly failures" (Miller and Friesen, 1978, p. 932). Moreover, Wiklund and Shepher (2005), indicate that this dimension implies the allocation of significant resources by the company to exploit opportunities or carry out strategies whose results are uncertain in unfamiliar situations.

According to the aforementioned, it can be indicated that the entrepreneurial orientation of a company is not an action carried out in a timely or unitary way, but rather it is an activity that implies a continuous strategic performance over time (Covin and Slevin, 1991), which translates into a generating process of the entrepreneurial strategy that decision-makers use to disseminate organizational purposes, maintaining their vision and creating sustainable competitive advantages.

Regarding the concept of innovation, Schumpeter (1934) demonstrated that, this takes place when a new good or change in its quality is introduced, a new production method, the opening to a new market, and the conquest of a new source of 
supply of raw materials or the creation of a new company in any industry. According to what he exposed, the development of the economy is due to innovation, understood as the dynamic process through which updated technologies replace the old ones, a process called "creative destruction". According to this point of view, economic growth takes place because of the process of destruction in which the old structure of the industry - its products, its processes, or its organization changes continuously due to innovation (Link, 1980). In this sense, innovative activity is the main source of innovation and economic progress (Nelson, 1991).

In addition to this, the Oslo Manual (2005, pp. 46) defines innovation as "the implementation of a new or significantly improved product (good or service), or process, a new marketing method, or a new organizational method in business practices, workplace organization or external relations".

Both Schumpeter (1934) and the Oslo Manual (2005) differentiate several types of innovation, namely: (i) Product innovation, (ii) Process innovation, (iii) Organizational innovation and (iv) Marketing innovation. In relation with the different types of innovation indicated before, the present study deals with Product Innovation, not only taking into account its popularity in most of the works (Souitaris, 2003), but also because it is a relevant aspect of sustained performance (Blundell et al., 1999), as well as due to its importance for the survival of a company (Dyer and Song, 1998), its profitability (Ali et al., 1993), its growth and its expansion into new areas (Danneels and Kleinschmidt, 2001). Thus, a company is innovative in products when it provides a new or significantly improved product (good or service) regarding to its characteristics or previous uses (Oslo Manual, 2005; Laursen and Salter, 2006).

Yet, the aim of innovation can be based on a new knowledge or on the reconfiguration, in a new way, of the existing one (Schumpeter, 1934; Drucker, 1985). From an economic point of view, a product, service or production process may be considered as an innovation, but it does not have to be something new in a strict sense, but new in the market where it wants to be introduced (Koellinger, 2008). In this sense, we can differentiate two other concepts within innovation, such as Incremental innovation and
Radical Innovation, depending on the degree of novelty of it (Schumpeter, 1934; Oslo Manual, 2005; Anderson and Tushman, 1990), so that the radical innovation consists in the contribution of goods and services that differ significantly in their characteristics or intended uses in relation to the products previously produced by the company and, the incremental innovation, which implies minor changes in the technical specifications of the products already existing in the company. It should also be noted that incremental and radical innovations bring distinct levels of risk and therefore, require different organizational and management capacities. Thus, radical innovations derive from the exploration of new capacities searching greater variations and novelties (March 1991). Companies introducing radical innovations need to substantially change their ways of operating by entering unknown markets and/or introducing new products based on technologies that are new to them. This type of innovation can give several results: on the one hand, it can lead to the destruction of competition (Menguc and Auh, 2010), and on the other hand, it can lead to cannibalization of current products and even changes in competition rules (Hurmelinna Laukkanen, Sainio, and Jauhiainen, 2008). On top of that, incremental innovation is the result of the exploitation of current capacities and in search of continuous improvements (March, 1991). The research of this type of innovation is one of the simplest tasks (Bessant et al, 2010) since the decisions on that subject are taken within the framework of a trajectory or an established technological paradigm (Dosi, 1982). Therefore, radical innovation, as opposed to incremental innovation, represents a higher risk strategy, but also a higher result (Bessant, Birkinshaw and Delbridge 2004; Sorescu and Spanjol, 2008).

Considering both concepts, entrepreneurial orientation and innovation, these are considered crucial factors for the growth and economic performance of companies. Schumpeter (1961) already warned of the importance of innovation and entrepreneurship, as they are central figures of economic growth and development. Based on his work, recent researches in the field of strategic management and evolutionary economics sustain that companies must be entrepreneurial and put innovation at the 
forefront of competition strategy (Teece, 2007). The main reason is because new products are the basis of the company's performance and profitability (Teece, 2007) and such innovations are fundamental for adapting to change market conditions (Nijssen, Hillebrand and Vermeulen, 2005; Bessant et al., 2005). Actually, according to Miles and Snow (1978) ideas, those companies that adopt an innovative orientation can respond quickly to changes in business setting and have a greater capacity to find and exploit new products and market opportunities. Furthermore, entrepreneurial orientation is an important factor not only for the survival of the company, but also for the improvement of its short and long-term results (Wiklund and Shepherd, 2005), since it implies "entrepreneurial strategy-making processes that key decision makers use to enact their firm's organizational purpose, sustain its vision, and create competitive advantage(s)" (Rauch et al., 2009, pp. 763). Moreover it involves a willingness to innovate to rejuvenate market offerings, take risks to try competitors toward new marketplace opportunities (Covin and Slevin, 1991). Thus, the implementation and integration of the strategy of entrepreneurial orientation, not only allows increasing the skills of the company to generate knowledge and provide solutions to fulfil the needs of current and potential consumers (Workman, 1993; Gatignon and Xuereb, 1997), but it also reduces their aversion to risk and thus, favours the development of knowledge generation mechanism and improves processes in product innovation (Miller, 1983; Lumpkin and Dess, 1996).

Considering the abovementioned, it would be considered that there are a positive relationship between entrepreneurial orientation and product innovation. The fundamental premise of Resource Based View theory is that firms' resources and capabilities are those that determining firm's capacity to innovate. Firms' resources can be tangible or intangible (Hall, 1992; Amit and Schoemaker, 1993). Tangible resources include capital, access to capital and location. Intangible resources consist of knowledge, reputation, skills, entrepreneurial orientation, etc. (Runyan et al., 2006). The considerations of entrepreneurial orientation like of opportunities and advantages, convert it into intangible resource and an important dimension of Resource Based View theory, which have impact in growth (Ferreira et al., 2011) and innovation (Poazi et al., 2017) of firms. From the strategic point of view, intangible resources may be more important, as soon as they are able to encourage the requirements for produce sustainable advantages which are more valuable, rare and inimitated by competitors (Bettis and Hitt, 1995; Barney, 1991), what mean that high stock of intangible resources, including entrepreneurial orientation, increases the probability of firm innovation (Nonaka, 1994).

In fact, Miller and Frisen (1982), just like more recently studies have been confirmed (Nasution et al., 2010), argued that more enterprising companies innovate more frequently.

In the same way, other authors confirm the positive relationship between entrepreneurial orientation and product innovation (Zhou et al., 2005), as well as with radical innovation (Zhou, Yim, and Tse, 2005). Similarly, Salavou and Lioukas (2003), in their study of Greek SMEs on the strategic sources of radical innovations in products, have concluded that entrepreneurial orientation has a positive effect on product innovations. In addition, more recent study of Boso et al. (2013), also confirmed the positive relationship between entrepreneurial orientation and product innovation. Likewise Avlonitisa and Salavoub (2007) showed that entrepreneurial companies, being more proactive and risky, develop and introduce more innovative products. Adding more relevance to the foregoing, the following hypotheses are proposed:

H11: Firm Entrepreneurial Orientation has a positive effect on Product Innovation.

H12: Firm Entrepreneurial Orientation has a positive effect on Incremental innovation.

H13: Firm Entrepreneurial Orientation has a positive effect on Radical Innovation.

\section{Family management}

The qualification of Family Firms exists due to the determination of a vision and control mechanisms of the company by a family, and its contribution to the creation of resources and unique capabilities within them (Sharma, 2004; Chrisman, Chua and Linz, 2003). Astrachan, Klein and Smyrnios (2002) developed a system of 
scales that differentiate the degree of family involvement into a company, these are:

- The experience, which measures the involvement of a family through the number of members and generations of the family with an active participation into the company;

- Culture, which measures the involvement of a family in the values of the company, as well as the commitment to it;

- Control, which measures the influence of a family on the ownership, management, and governance of the company.

Villalonga and Amit (2006) also differentiate three ways in which families can be involved in a company, this is through management, ownership and control.

In Europe, the national associations of family businesses have adopted as a formal definition, the proposal made by the European Family Business Group (GEEF) in 2008 considers a family business to be one in which:

- Most of the votes are owned by the person or persons of the family that founded or acquired the company;

- Most votes can be direct or indirect;

- At least one representative of the family participates in the management or governance of the company;

- Listed companies are considered a family business if the person who founded or acquired the company, or their family members or descendants own $25 \%$ of the voting rights to which the share capital is entitled.

In the same way, it can be indicated that the family involvement in a company can be carried out in different ways, and in the present work it is understood by the family management, the participation of the family members in the management activities of a family firm, measured by the family participation in the management of the organization and the structure of the company (Zahra 2005).

In the context of entrepreneurship, family firms are an unique and relevant context to analyse, either by the configuration of resources and capabilities they have and their relationship with entrepreneurial behaviour (Sirmon and Hitt, 2003; Dyer, 2006; Eddleston, Kellermanns, and Sarathy, 2008) or the relevant effect of family management in the process of decision making (Nordqvist, Habbershon, and Melin, 2008).

In general, family-managed firms are characterized by their greater ability to develop an entrepreneurial performance, since their survival depends on their ability to enter new markets in which they can offer innovative products and services (Zahra, Hayton, and Salvato, 2004). This is due to a series of characteristics present in this type of company (Casillas and Moreno, 2010), such as: (i) its greater long-term orientation, which allows it to develop better long-term business strategies (Ward, 1997), including innovation strategies, since in this situation, they are more likely to support innovation as a source of growth and wealth (Zahra, Hayton and Salvato, 2004) and as a survival mechanism to protect their competitiveness over time; (ii) its greater degree of centralization, which makes the process of decision-making faster, and therefore, the implementation and development of innovation too; (iii) and the strength of the interests between the owners and the managers, since the greater degree of concentration between ownership and management, the innovation projects proposed by the family are more defended, and consequently, the allocation of the resources for its development is faster and more efficient, in addition to having greater control over the measures taken by management (Donckels and Fröhlich, 1991).

However, the resources available to the company are small, and considering their aversion to debt at the time of making capital investments (Galve Gorriz and Salas Fumas, 1996), family-managed firms have difficulties to develop proactive strategies. It may be noted that not only risk aversion affects the resources available to the family business, but also capital restrictions, which jointly limit the possibility of initiating costly innovation projects. For fear of losing control in decision making, family managed firms are slightly inclined to access capital markets (Kets de Vries 1993), what causes that they are restricted regarding their financial resources and thus, their opportunities to finance innovation activities as well as proactive projects.

Furthermore, family managed firms have a greater aversion to risk as a result of the superposition of the objective of survival of the company, the fortune and social reputation of the family, against the profitability objective (Zahra 2005, Gómez-Mejía et al., 2007), and its more conservative character of business assets, which represents the personal wealth of the family (Gómez-Mejía et al., 2007). Therefore, its aversion to indebtedness (Galve Gorriz and Salas Fumas, 1996) which reduces the availability of financial resources, that causes firstly, family managed firms have limited financial resources, and secondly, aim for safer projects (Wright et al., 2002). 
The Resource Based View theory suggests that resources and capabilities are drivers in innovation of firms (Poazi et al., 2017). Rather, these resources must also be managed effectively and appropriately (Hitt, Ireland, and Hoskisson, 2001) in order to produce value and archive the proposed results. As it is said before, family managed firms rarely have all of the needed resources, particularly financial resources, since these firms avoid sharing equity with nonfamily members and also, they have some limitation to manage them, due to the prioritization of their particular goals, the retaining of interfamily relatedness and the superposition of the objective of survival of the company. This causes a loss of efficiency of the process of strategic decision-making, including those related to innovation (Le Breton-Miller and Miller, 2009), and a greater difficulty in developing proactive projects, what, as we have suggested, decreases the positive relationship between entrepreneurial orientation and product innovation (Choi et al., 2015).

In order to emphasise aforementioned and considering that entrepreneurial orientation is a resource-consuming strategy orientation (Covin and Slevin, 1991) which enhance to make large resource contributions, the following hypotheses are proposed:

H21: Family Management weakness the effect of the Firm Entrepreneurial Orientation on Product Innovation.

H22: Family Management weakness the effect of the Firm Entrepreneurial Orientation on Incremental Innovation.

$\mathrm{H} 23$ : Family Management weakness the effect of the Firm Entrepreneurial Orientation on Radical innovation.

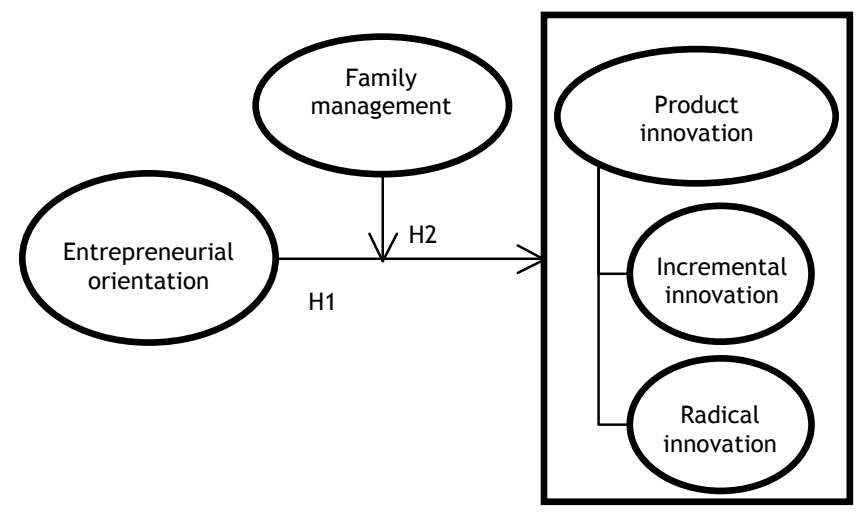

\section{Methodology}

\section{Data collection and sample}

The data collection for the realization of the study has been carried out through a questionnaire made to a total of 634 managers of companies located in the Region of Murcia (Spain), as a part of research activity promoted by the "Observatorio Económico de la PYME", a Research Centre for SME's funded by the Instituto de Fomento de la Region de Murcia ${ }^{1}$.

The Region of Murcia is a fairly representative territory of the national panorama, since, in relation to the Spanish national average $(99,90 \%)$, it is composed of a total of $99,92 \%$ of micro, small and medium enterprises (SMEs). In this sense, SMEs are defined, according to Recommendation 2003/361/CE, to micro, small and medium enterprises that have less than 250 employees and whose annual turnover does not exceed 50 million euros or whose balance sheet annual does not exceed 43 million euros.

The sample selection process (design process) was designed in accordance with the objectives of the study and the characteristic structure of the region following the stratified sampling principles in finite populations. The population of firms was segmented by size and industry. The number of firms in each stratum was implemented according to the information contained in the Companies Registration Office following the criteria of the "Instituto Nacional de Estadística”' (Spanish Statistical Office).

The resulting sample is formed by 634 family businesses. In turn, within the family businesses, there are family businesses managed by family members, 571 (90,06\%), and companies managed by non-family members, $63(9,94 \%)$, a similar proportion to other studies carried out (Huybrechts et al., 2013). On the other hand, family businesses have been classified, firstly, according to the sector in which they carry out their business activity, thus differentiating between the Industry $(51,42 \%)$, Construction $(10,88 \%)$ and Services ( $37,70 \%)$; and secondly, depending on their size, taking into account the number of employees working in them, differentiating between Small $(83,75 \%)$, Medium $(14,36 \%)$ and Large $(1,89 \%)$.

The table 1 collects the final distribution of the sample.

Figure 1 Hypotheses.

\footnotetext{
${ }^{1}$ The Instituto de Fomento de la Región de Murcia is the development agency of the Murcia's region. It is a public institution that belongs to the Manufacturing, Firm and Innovation Office.
}

Fredyna, T. Ruíz-Palomo, D. Dieguez, J. (2019). Entrepreneurial orientation and product innovation. The moderating role of family involvement in management. European Journal of Family Business, 9(2), 128-145. 
a $25,174 \%$ of the variance. These results suggested that the bias of the common method variance was not relevant in our study (Podsakoff y Organ, 1986).

\begin{tabular}{|c|c|c|}
\hline & $\mathrm{N}$ & $\%$ \\
\hline Family-Managed firms & 571 & $90,06 \%$ \\
\hline Non-Family Managed firms & 63 & $9,94 \%$ \\
\hline Manufacturing & 326 & $51,42 \%$ \\
\hline Construction & 69 & $10,88 \%$ \\
\hline Services & 239 & $37,70 \%$ \\
\hline Small firm (up to 50 employees) & 531 & $83,75 \%$ \\
\hline Medium firm (from 50 to 250 employees) & 91 & $14,36 \%$ \\
\hline Large firm (more than 250 employees) & 12 & $1,89 \%$ \\
\hline Total & 634 & $100,00 \%$ \\
\hline
\end{tabular}

The estimation of the sample considers in the worst case (relative frequency of answers in a specific item is $p=q=0.5$ ), to a maximum error of $4,06 \%$ at a confidence level of $95 \%$. Companies that chose to not participate in the project were replaced with similar (random election) firms in the same industry and geographic area. Information was collected through personal interviews with firm managers during April 2010 and July 2010, using a self-managed questionnaire addressed to firm's CEO. SME's managers are the most important decision makers (Van Gils, 2005) and managerial perceptions influence to a significant degree the firm's strategic behavior (O’Regan \& Sims, 2008). Control tests were carried out during the elaboration process of the survey. To test the validity of the survey, the bias of non-response was analyzed. Due to the nature of the data, it is possible that the relations between the variables were inflated as a consequence of the common method variance, since the same source is used to gather data for both the independent and dependent variable. This is why the bias of potential problem of the variance of the common method was also analyzed. To test for nonresponse bias, we used late respondents as surrogates for non-respondents Nwachukw et al., 1997), as well as the responses of the companies that responded to the first round of interviews ( $81 \%$ of the sample) were contrasted with those late responses $(19 \%$ of the sample), and the results obtained showed no significant differences between the two groups, taking into account the Student $\mathrm{t}$ and chi-squared statistics. Considering these outcomes, non-response and industry bias were not found. Likewise, to test the bias of potential problem of the variance of the common method, we used the Harman's single-factor test suggested by Podsakoff and Organ (1986). In this way, we have realized a factorial analysis including all the dependent variables and independent variables, achieving to explain a high amount of the variance (Christmann, 2000). In the factorial analysis executed in our study, three factors were obtained (KMO: 0.841; Bartlett sphericity test Sig. 0.000) which explained a $58,430 \%$ of the total variance. Between these factors, the first one collects the dependents variables explained

\section{Variables definition}

\section{Product innovation}

A company is innovative in products when it introduces a new or significantly improved good or service with respect to its characteristics or previous uses (Manual de Oslo, 2005; Laursen y Salter, 2006).

There are two types of product innovation: (i) on the one hand, radical innovation, which consists of the contribution of goods and services that differ significantly in their characteristics or intended uses with respect to the products previously produced by the company; and (ii) on the other, incremental innovation, which consist of a series of minor changes in the technical specifications of the products already existing in the company (Oslo Manual, 2005).

Product innovation can be measured through two approaches, first, an objective approach, and secondly, one subjective approach. The objective approach is used to measure the innovation from quantitative data (number of patents, number of new products, investments cost), while the subjective approach is based on the firm's manager or owner's perception about the innovative activity of the firm. In this work, we have opted for the subjective approach because it is the most appropriate for the case of SMEs and avoids underestimating the innovative activity of SMEs, in particular incremental activity, which the objective approach may overlook (Hughes, 2001). Subjective measures were highly correlated with objective measures of innovation and allowed comparisons among firms (Frishammar and Hörte, 2005). Also, subjective measures are valid to identifying and monitoring obstacles that decrease innovation among SMEs (Kalantaridis and Pheby, 1999). Furthermore, the results of Denison and Mishra (1995, pp. 219) supported that "subjective measures of effectiveness are better suited for the comparison of a disparate set of firms than are the objective measures of effectiveness"

\section{Entrepreneurial Orientation}

Based on the conceptualization of Miller (1983), and other previous studies (Naman and Slevin, 1993; Wiklund and Shepherd, 2005), three dimensions of entrepreneurial orientation have been used in the present work to measure the entrepreneurial orientations, which are innovativeness, risk-taking, proactiveness. The dimension of innovativeness refers to the predisposition of the company to support research and technological development activities via R\&D; the risk-taking dimension 
implies keeping an active position in situations of uncertainty and carrying out risky projects; and the dimension of proactivity implies the maintenance of a prospective position in front of the competition, identifying new business opportunities in the market and carrying out actions in advance that are later imitated by the competition.

Considering a combination of three dimensions of entrepreneurial orientation, we obtained this variable through a factor analysis. The result obtained with the combination of the three dimensions can be seen in table 2 .

\section{Family management}

The family management has been measured through the participation of family members in the management of the company. In this sense, family involvement is represented by the variable called Family Management, which has been measured as a binary variable, which takes value 1 when family members hold mostly the management positions (Vanderkerkhof et al., 2015), and the value 0 when the management positions are hold mostly by professionals from outside the family.

Table 2 summarizes the contents relating to the definition of the variables in the models

Table 2 Variables definition.

\begin{tabular}{|c|c|c|}
\hline Variable & Definition & Measure \\
\hline $\begin{array}{l}\text { Family } \\
\text { Management }\end{array}$ & $\begin{array}{l}\text { Family versus non-family } \\
\text { management }\end{array}$ & 1: Family members. 0: Non - family members. \\
\hline $\begin{array}{l}\text { Entrepreneurial } \\
\text { Orientation }\end{array}$ & $\begin{array}{l}\text { Entrepreneurial } \\
\text { orientation of the } \\
\text { company }\end{array}$ & $\begin{array}{l}\text { This variable has been obtained through a factorial analysis of the different questions of the survey } \\
\text { related to the firm entrepreneurial orientation. } \\
\text { The questions were: } \\
\text { Please indicate the degree of agreement with the following statements (1: very unfavorable; } 5 \text { : very } \\
\text { favorable): } \\
\text { 1- The managers of my company support research and technological development activities } \\
\text { 2- My company is very inclined to take on risky projects with a lot of market potential } \\
\text { 3- The actions carried out in my company are soon imitated by the competition } \\
\text { 4- My company has a great ability to identify new business opportunities } \\
\text { 5- My company adopts an active position in uncertainty situations } \\
\text { The results were: } \\
\text { - Explained variance: } 48,5 \% \text {; } \\
\text { - } x^{2}(10)=849,43 ; \\
\text { - Prob>x }<0,000 ; \\
\text { - KMO: } 0,772 ; \\
- \text { Cronbach a: } 0,729 \text {. }\end{array}$ \\
\hline $\begin{array}{l}\text { Product } \\
\text { innovation } \\
- \text { Incremental } \\
\text { innovation } \\
\text { - Radical } \\
\text { innovation } \\
\end{array}$ & $\begin{array}{l}\text { Existence and } \\
\text { importance of Product } \\
\text { innovation into the } \\
\text { company }\end{array}$ & $\begin{array}{l}\text { With a range } 0-5 \text {, this variable was built as the average of two sets of dummy and complementary } \\
\text { licker variable, where } 0: \text { no innovation; } 1-5: \text { the higher of the value, the higher the importance of the } \\
\text { innovation. The questions were: Has the firm made any changes or improvements in its products in } \\
\text { the past year considering }(\mathrm{a}) \text { : incremental innovation; (b): radical innovation? If so, indicate the } \\
\text { degree of importance of these changes for your business. }\end{array}$ \\
\hline Performance & $\begin{array}{l}\text { Evolution of certain } \\
\text { aspects of performance } \\
\text { in the company. }\end{array}$ & $\begin{array}{l}\text { This variable has been obtained through a factorial analysis of the different questions of the survey } \\
\text { related to the performance of a company. } \\
\text { The questions were: Please indicate how has the evolution been of the following aspects of your } \\
\text { business in the last two years ( } 1 \text { : very unfavorable; } 5 \text { : very favorable): } \\
\text { 1- Improvements in market share; } \\
\text { 2- Improvements in profitability; } \\
\text { 3- Improvements in productivity. } \\
\text { The results were: } \\
\text { - Explained variance: } 78,9 \% \text {; } \\
\text { - } x^{2}(3)=1314,49 ; \\
\text { - Prob> } x^{2}<0,000 ; \\
\text { - KMO: } 0,728 ; \\
\text { - Cronbach a: } 0,867 \text {. }\end{array}$ \\
\hline Financial Position & $\begin{array}{l}\text { Financial aspects in the } \\
\text { company }\end{array}$ & $\begin{array}{l}\text { This variable has been obtained through a factorial analysis of the different questions of the survey } \\
\text { related to financial position of the company. } \\
\text { The questions were: Please indicate how has the evolution been of the following aspects of your } \\
\text { business in the last two years (1: very unfavorable; } 5 \text { : very favorable): } \\
\text { 1- Liquidity and cash; } \\
\text { 2- Leverage --- indebtedness; } \\
\text { 3- Debt service capacity; } \\
\text { 4- Cost of debt; } \\
\text { 5- Self-financing capability (to retain earnings). } \\
\text { The results were: } \\
\text { - Explained variance: } 63,2 \% \text {; } \\
\text { - } x^{2}(10)=1877,13 ; \\
\text { - Prob> } x^{2}<0, .000 ; \\
\text { - KMO: } 0,838 ; \\
\text { - Cronbach a: } 0,853 \text {. }\end{array}$ \\
\hline Size & Number of employees & Logarithm (ln) of the number of employees of the company \\
\hline Age & $\begin{array}{l}\text { The number of years } \\
\text { since the firm started } \\
\text { the business }\end{array}$ & Number of years since the firm was created \\
\hline Industry & Sector of the activity & $\begin{array}{l}\text { 1. Manufacturing. } \\
\text { 2. Construction. } \\
\text { 3. Services. }\end{array}$ \\
\hline
\end{tabular}


existence of multicollinearity has been contrasted through the variance inflation factor

\section{Results}

Table 3 summarizes the main descriptive statistics of the variables and reports the means, standart desviations, as well as minimum and maximum values of the variables for the sample. Beside, table 4 gathers the bivariate correlations between variables.

To verify the proposed hypotheses Ordinary Least Squares (OLS) general linear regression models were used. Nine models were estimated. Table 5 displays the resulting regression models.

Table 3 Descriptive statistics.

\begin{tabular}{|c|c|c|c|c|}
\hline & Mean & $\begin{array}{c}\text { Standart } \\
\text { desviation }\end{array}$ & Min & Max \\
\hline $\begin{array}{l}\text { Product } \\
\text { innovation }\end{array}$ & 3,039 & 3,321 & 0,000 & 10,00 \\
\hline $\begin{array}{l}\text { Incremental } \\
\text { innovation }\end{array}$ & 1,702 & 1,918 & 0,000 & 5,000 \\
\hline $\begin{array}{c}\text { Radical } \\
\text { innovation }\end{array}$ & 1,338 & 1,836 & 0,000 & 5,000 \\
\hline $\begin{array}{c}\text { Entrepreneurial } \\
\text { Orientation }\end{array}$ & 0,000 & 1,000 & $-2,776$ & 2,417 \\
\hline $\begin{array}{c}\text { Family } \\
\text { management }\end{array}$ & 0,901 & 0,299 & 0,000 & 1,000 \\
\hline Performance & 0,000 & 1,000 & $-2,074$ & 2,270 \\
\hline $\begin{array}{l}\text { Financial } \\
\text { Position }\end{array}$ & 0,000 & 1,000 & $-2,189$ & 2,182 \\
\hline Age & 22,98 & 16,505 & 0,000 & 159,0 \\
\hline Size & 14,566 & 1,527 & 8,854 & 18,891 \\
\hline Industry & 1,863 & 0,935 & 1,000 & 3,000 \\
\hline
\end{tabular}

Before describing the results of each model, it is necessary to indicate that in all of them the
Table 4 Correlations matrix.

\begin{tabular}{|c|c|c|c|c|c|c|c|c|c|c|c|}
\hline & & 1 & 2 & 3 & 4 & 5 & 6 & 7 & 8 & 9 & 10 \\
\hline 1 & $\begin{array}{l}\text { Product } \\
\text { innovation }\end{array}$ & 1 & & & & & & & & & \\
\hline 2 & $\begin{array}{l}\text { Incremental } \\
\text { innovation }\end{array}$ & $0,8898^{* * *}$ & 1 & & & & & & & & \\
\hline 3 & $\begin{array}{c}\text { Radical } \\
\text { innovation }\end{array}$ & $0,8791^{* * *}$ & $0,5647^{* * *}$ & 1 & & & & & & & \\
\hline 4 & $\begin{array}{l}\text { Entrepreneurial } \\
\text { Orientation }\end{array}$ & $0,3120^{* * *}$ & $0,2525^{* * *}$ & $0,3002^{* * *}$ & 1 & & & & & & \\
\hline 5 & $\begin{array}{c}\text { Family } \\
\text { management }\end{array}$ & $-0,1422^{* * *}$ & $-0,1232^{* * *}$ & $-0,1286^{* * *}$ & $-0,0916^{* *}$ & 1 & & & & & \\
\hline 6 & Performance & $0,1400^{* * *}$ & $0,1320^{* * *}$ & $0,1152^{* * *}$ & $0,3165^{* * *}$ & $-0,0847^{* *}$ & 1 & & & & \\
\hline 7 & $\begin{array}{l}\text { Financial } \\
\text { Position }\end{array}$ & $0,1929^{* * *}$ & $0,2015^{* * *}$ & $0,1381^{* * *}$ & $0,2227^{* * *}$ & $-0,0861^{* *}$ & $0,3950^{* * *}$ & 1 & & & \\
\hline 8 & Age & $0,0959^{* *}$ & $0,0983^{* *}$ & $0,0708^{*}$ & 0,0379 & $-0,0867^{* *}$ & 0,0188 & $0,1348^{* * *}$ & 1 & & \\
\hline 9 & Size & $0,1553^{* * *}$ & $0,1289^{* * *}$ & $0,1459^{* * *}$ & $0,1079^{* *}$ & $-0,1954^{* * *}$ & $0,1461^{* * *}$ & $0,1691^{* * *}$ & $0,1841^{* * *}$ & 1 & \\
\hline \multirow[t]{2}{*}{10} & Industry & $-0,1560^{* * *}$ & $-0,1127^{* * *}$ & $-0,1644^{* * *}$ & $-0,0901^{* *}$ & 0,0246 & 0,0428 & $-0,0330$ & $-0,1749^{* * *}$ & $-0,059$ & 1 \\
\hline & & 1 & 2 & 3 & 4 & 5 & 6 & 7 & 8 & 9 & 10 \\
\hline
\end{tabular}

(VIF), obtaining values between 1,12 and 3,45 , depending on the estimated model. Therefore, we discarded the presence of multicollinearity. Also, all the models have been estimated applying the robust estimator of White, for which consistent standard errors have been obtained, and, in accordance with that, we ruled out the problem of the heteroscedasticity. Finally, the obtained statistically significant $F$ values confirm the overall validity of the estimated models and the joint significance of the estimated parameters.

In order to make the estimations of the regression models, we have obtained different models of direct relationship between the Entrepreneurial Orientation and Family Management and Product Innovation (Models 1 and 2), Incremental Innovation (Models 4 and 5) and Radical Innovation (Models 7 and 8), adding in turn, to the previous models, a moderating variable, this is the Family Management, in order to estimate the possible effect of interaction of family involvement on the effect of the Entrepreneurial Orientation on Product Innovation (Model 3), Incremental Innovation (Model 6) and Radical Innovation (Model 9). Thus, the following steps have been followed to estimate each model: at first, Models 1, 4 and 7, took only the control variables into consideration; then, Models 2, 5 and 8, incorporated the direct relationship variables; and finally, Models 3, 6 and 9, incorporated the interaction effect variable. 


\begin{tabular}{|c|c|c|c|c|c|c|c|c|c|}
\hline & \multicolumn{3}{|c|}{ Product innovation } & \multicolumn{3}{|c|}{ Incremental innovation } & \multicolumn{3}{|c|}{ Radical innovation } \\
\hline & MODEL 1 & MODEL 2 & MODEL 3 & MODEL 4 & MODEL 5 & MODEL 6 & MODEL 7 & MODEL 8 & MODEL 9 \\
\hline \multirow[t]{2}{*}{ Entrepreneurial Orientation (EO) } & & 0.897 & 1,738 & & 0,398 & 0,766 & & 0,498 & 0,971 \\
\hline & & $(0.141)^{* * *}$ & $(0,337)^{* * *}$ & & $(0,086)^{* * *}$ & $(0,201)^{* * *}$ & & $(0,078)^{* * *}$ & $(0,199)^{* * *}$ \\
\hline \multirow[t]{2}{*}{ Family management } & & -1.014 & $-0,879$ & & $-0,505$ & $-0,446$ & & $-0,509$ & $-0,433$ \\
\hline & & $(0.441)^{* *}$ & $(0,423)^{* *}$ & & $(0,263)^{*}$ & $(0,258)^{*}$ & & $(0,242)^{* *}$ & $(0,233)^{*}$ \\
\hline \multirow[t]{2}{*}{ EO $\times$ Family management } & & & $-0,942$ & & & $-0,412$ & & & $-0,530$ \\
\hline & & & $(0,370)^{* *}$ & & & $(0,220)^{*}$ & & & $(0,216)^{* *}$ \\
\hline \multirow[t]{2}{*}{ Performance } & 0,265 & 0,006 & 0,027 & 0,103 & $-0,015$ & $-0,006$ & 0,162 & 0,021 & 0,033 \\
\hline & $(0,145)^{*}$ & $(0,144)$ & $(0,144)$ & $(0,086)$ & $(0,087)$ & $(0,087)$ & $(0,082)^{* *}$ & $(0,081)$ & $(0,081)$ \\
\hline \multirow[t]{2}{*}{ Financial position } & 0,419 & 0,330 & 0,350 & 0,303 & 0,264 & 0,272 & 0,116 & 0,066 & 0,077 \\
\hline & $(0,151)^{* * *}$ & $(0,139)^{* *}$ & $(0,139)^{* *}$ & $(0,088)^{* * *}$ & $(0,085)^{* * *}$ & $(0,085)^{* * *}$ & $(0,084)$ & $(0,078)$ & $(0,078)$ \\
\hline \multirow[t]{2}{*}{ Age } & 0,007 & 0,005 & 0,005 & 0,005 & 0,005 & 0,004 & 0,002 & 0,001 & 0,000 \\
\hline & $(0,010)$ & $(0,009)$ & $(0,009)$ & $(0,005)$ & $(0,005)$ & $(0,005)$ & $(0,005)$ & $(0,005)$ & $(0,005)$ \\
\hline \multirow[t]{2}{*}{ Size } & 0,233 & 0,177 & 0,166 & 0,098 & 0,071 & 0,067 & 0,135 & 0,105 & 0,099 \\
\hline & $(0,094)^{* *}$ & $(0,093)^{*}$ & $(0,093)^{*}$ & $(0,055)^{*}$ & $(0,054)$ & $(0,055)$ & $(0,053)^{* *}$ & $(0,052)^{* *}$ & $(0,052)^{*}$ \\
\hline \multirow[t]{2}{*}{ Industry } & $-0,494$ & $-0,429$ & $-0,431$ & $-0,188$ & $-0,162$ & $-0,163$ & $-0,305$ & $-0,267$ & $-0,268$ \\
\hline & $(0,150)^{* * *}$ & $(0,146)^{* * *}$ & $(0,145)^{* * *}$ & $(0,089)^{* *}$ & $(0,087)^{*}$ & $(0,087)^{*}$ & $(0,082)^{* * *}$ & $(0,080)^{* * *}$ & $(0,080)^{* * *}$ \\
\hline \multirow[t]{2}{*}{ Constant } & 0,443 & 2,111 & 2,142 & 0,533 & 1,348 & 1,362 & $-0,090$ & 0,763 & 0,781 \\
\hline & $-1,411$ & $-1,559$ & $-1,550$ & $(0,818)$ & $(0,883)$ & $(0,878)$ & $(0,792)$ & $(0,864)$ & $(0,861)$ \\
\hline $\mathrm{F}$ & $9,90^{* * *}$ & $16,37^{* * *}$ & $15,70^{* * *}$ & $8,49^{* * *}$ & $12,04^{* * *}$ & $11,13^{* * *}$ & $7,99^{* * *}$ & $14,16^{* * *}$ & $13,74^{* * *}$ \\
\hline $\mathrm{R}^{2}$ & 0,08 & 0,15 & 0,16 & 0,06 & 0,11 & 0,11 & 0,06 & 0,14 & 0,14 \\
\hline VIF & 1,12 & 1,14 & 3,45 & 1,12 & 1,14 & 3,45 & 1,12 & 1,14 & 3,45 \\
\hline
\end{tabular}

Ordinary Least Squares regressions, No standardized OLS coefficients reported (Robust standard errors in parentheses), ${ }^{* * *} \mathrm{p}<0,01 ;{ }^{* *} \mathrm{p}<0,05 ;{ }^{*} \mathrm{p}<0,10$.

Firstly, as we indicated, in order to measure the direct effect of Entrepreneurial Orientation and Family Management on Product Innovation, Models 2, 5 and 8 were estimated.

$Y i=B 0+B 1 E O+B 2$ Family management $+B 3$

Performance + B4 Financial position $+B 5$ Age + $B 6$ Insize $+B 7$ Sector $+\varepsilon i$

These models not only measure the influence of Entrepreneurial Orientation and Family Management in Product Innovation (Model 2), but also differentiate such influence into Radical innovation (Model 5) and Incremental innovation (Model 8). In Model 2, the dependent variable (Yi) is Product Innovation, and in Models 5 and 8, the dependent variables are Incremental Innovation and Radical Innovation respectively. The global validity of the models was confirmed because the $F$ value was significant $\left(F=16,37^{* *}\right.$; $\left.\mathrm{F}=12,04^{* *} ; \mathrm{F}=14,16^{* *}\right)$. In all models we found a positive and significant Beta associated with Entrepreneurial Orientation $\quad\left(B 1=0,897^{* * *}\right.$; $B 1=0,398^{* * *} ; B 1=0,498^{* * *}$ ) and a negative and significant Beta associated with Family Management $\quad\left(B 2=-1,014^{* *} ; \quad B 2=-0,5045^{*} ; \quad B 2=-\right.$ $\left.0,509^{* *}\right)$. These results imply, on the one hand, that Entrepreneurial Orientation positively affects Product Innovation, Incremental innovation and Radical Innovation, verifying H11, $\mathrm{H} 12, \mathrm{H} 13$, and, on the other hand, that Family Management has a negative effect on Product Innovation, Incremental innovation and Radical Innovation.

Also, Models 3, 6 and 9 have measured the moderating effect of Family Management on the relationship between Entrepreneurial Orientation and Product Innovation, Incremental innovation and Radical Innovation.

$Y i=B 0+B 1 E O+B 2$ Family management $+B 3$

EO*Family management $+B 4$ Performance $+B 5$

Financial position $+B 6$ Age $+B 7$ Insize $+B 8$ sector $+\varepsilon i$

In these models, the dependent variable $(\mathrm{Yi})$ is Product Innovation (Model 3), Incremental Innovation (Model 6) and Radical Innovation (Model 9). The global validity of the models was confirmed because the $F$ value was significant $\left(F=15,70^{* *} ; F=11,13^{* *} ; F=13,74^{* *}\right)$. Furthermore, in all models we found a positive and significant Beta $\left(B 3=-0,942^{* *} ; \quad B 3=-0,412^{*} ; \quad B 3=-0,530^{* *}\right)$, what indicates that Family Management 
moderate the effect of Entrepreneurial Orientation on Product Innovation, Incremental innovation and Radical Innovation and verify the hypotheses $\mathrm{H} 21, \mathrm{H} 22$ y $\mathrm{H} 23$.

In addition, once the hypotheses $\mathrm{H} 21, \mathrm{H} 22$ y $\mathrm{H} 23$ were verified, we propose some graphics in figure 2 in order to better visualize and interpret the moderating effect of Family Management on the relationship between Entrepreneurial Orientation and Product Innovation, Incremental innovation and Radical Innovation.
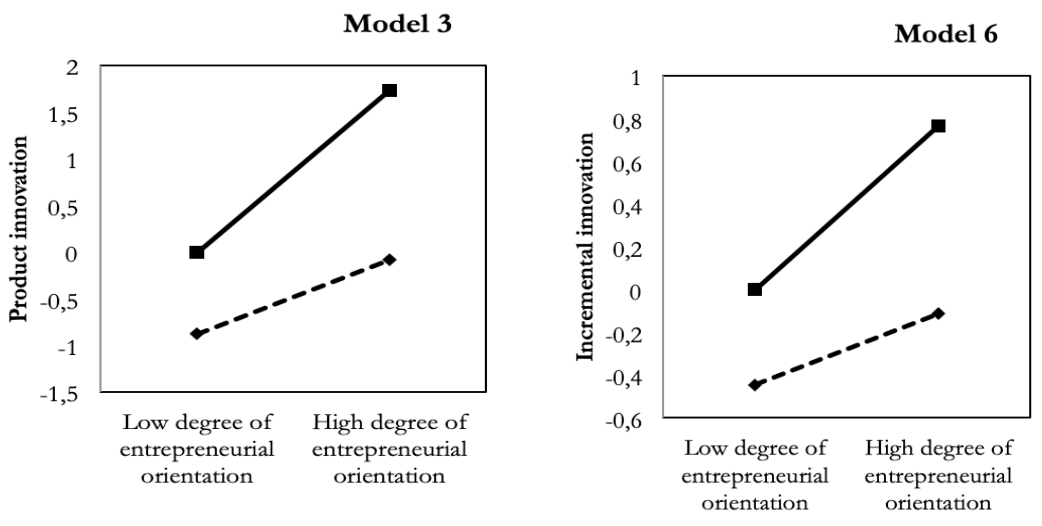

$-\downarrow-$ Family management

$\longrightarrow$ Non - family

management

Figure 2 Moderating effects.

In the graphics shown in figure 2 it can be seen that in family-managed firms, the positive effect of Entrepreneurial Orientation on Product Innovation, Incremental Innovation and Radical Innovation is lower in non-family managed firms. The table 6 gathers the quantitative marginal effects of the analyzed moderating effect.

Table 6 Marginal effects of Entrepreneurial Orientation on Innovation depending on the family involvement in the management of the company.

\begin{tabular}{|c|c|c|}
\hline Margina & $\begin{array}{l}\text { ffects of Entre } \\
\text { Orientation } \\
\left(\frac{\partial \widehat{Y}_{i}}{\partial O \text { REMP }_{\mathrm{i}}}\right)\end{array}$ & eneurial \\
\hline $\begin{array}{l}\text { Product } \\
\text { innovation }\end{array}$ & $\begin{array}{l}\text { Incremental } \\
\text { innovation }\end{array}$ & $\begin{array}{c}\text { Radical } \\
\text { innovation }\end{array}$ \\
\hline 0,796 & 0,354 & 0,441 \\
\hline 1,738 & 0,766 & 0,971 \\
\hline
\end{tabular}

Some of concerning control variables were resulted statistically significant in the estimated models and, consequently, have an effect on Entrepreneurial Orientation and / or Product innovation.

\section{Discussion and Conclusions}

The entrepreneurial orientation can be considered as practice, philosophy or strategic process that leads companies to innovation (Miller and Friesen, 1982; Wiklund and Shepherd, 2005). Innovation is a relevant factor of economic progress (Nelson, 1991) and it is an important aspect for the sustained performance (Blundell et al., 1993), survival (Dyer and Song, 1998), profitability (Ali et al., 1993), growth and expansion (Danneels and Kleinschmidt, 2001) of the company. This is also true that family firm context presents big interest in the field of entrepreneurial orientation (Zahra et al., 2004; Steier, 2007; Steier, 2009) and innovation (Craig and Moores, 2006; Pittino and Visintin, 2009). Thus, there are many researches that analyse the relationship between the abovementioned variables in different ways, but, unfortunately, the study of the relationship between entrepreneurial innovation and product innovation distinguishing between incremental and radical innovation has been practically nonexistent as far as we know. 
Additionally, to complete our research, we also analysed the moderating effect of family managed firms on the abovementioned relationship.

To achieve our objective, we firstly studied the relationship between entrepreneurial orientation and product innovation, including radical innovation and incremental innovation. Using Miller's (1983) three original dimensions characteristic of entrepreneurial orientation (Naman and Slevin, 1993; Wiklund and Shepherd, 2005), the obtained results supported the positive association between entrepreneurship and product innovation (Zhou et al., 2005; Nasution et al. 2010; Fernández-Mesa et al., 2012), and radical innovation (Avlonitisa and Salavoub, 2007; Zhou, Yim, and Tse, 2005; Salavou and Lioukas, 2003), as well as indicated a favourable influence of entrepreneurial orientation on incremental innovation. After these results, we could reaffirm and reinforce that entrepreneurial orientation has a positive effect on the product innovation, including incremental innovation and radical innovation.

Secondly, considering the importance that product innovation has for family firms (De Massis et al., 2013), we analysed the influence of the family involvement in the management of the firm on the relationship between entrepreneurial orientation and product innovation, also distinguishing between radical innovation and incremental innovation. Our findings showed that family managed firms weaken the relationship between entrepreneurial orientation and product innovation.

These results are consistent with the work of Chen and Hsu (2009) and the traditional vision of family forms as more conservative organizations (Sharma, Chrisman, and Chua, 1997), less keen to change (Kets de Vries, 1993; Ward, 1997), more risk-averse (Naldi et al., 2007), and with greater difficulty to get access to capital markets (Kets de Vries, 1993). Therefore, the obtained results reveal that family involvement in firms' management debilities the positive effect of entrepreneurial orientation on product innovation, including radical and incremental innovation.

Nevertheless, the above not mean that family managed firms do not innovate. Analysing the effect of family management on radical and incremental innovation, our results showed, not very deeply, how the family management has a major moderating effect on radical innovation versus incremental innovation. The aforementioned difference is due to the fact that incremental innovation is derived from exploiting current resources and capabilities and searching of continuous improvements of the firm and has less impacts on processes and methods of operating of the company (March, 1991), and it is not as risky and does not require as much financial resources as radical innovation (Bessant, Birkinshaw and Delbridge 2004; Sorescu and Spanjol, 2008).

In conclusion, our study provides a new contribution in the literature of family business, particularly with the analysis how the family management moderates the effect of the entrepreneurial orientation on product innovation relationship, as far as we know, the previous literature has not analysed yet. The study's findings suggest that high level of family management reduces the effect of entrepreneurial orientation on product innovation, specifically in radical innovation. On the contrary, when family involvement on manager is low, the entrepreneurial orientation effect on product innovation, radical innovation and incremental innovation is higher. Therefore, the family management should be taken into account in the field of family firms due to its importance in innovation, since that creates wealth and opens up new business opportunities, and entrepreneurship, as they are central figures of economic growth and development (Schumpeter, 1961).

This conclusion is important for family managed firms due to (i) it could help stakeholders and policy-makers to make decisions about subsidies, investments, training, etc, which would help firms to improve their efforts on product innovation. In this sense, this negative moderator effect of family management could be corrected by the participation of non-family members in firms' management or with the professionalization and teaching of their own managers. Also, public institutions should facilitate family managed firms greater resources so that they can innovate more, what will not only improve the development of family businesses, but also national economy. Furthermore, due to that Product Innovation is a key factor of industrial competitiveness and national development, being an important determinant of sustained yield (Blundell et al., 1999).

This study is not free from limitations. Firstly, the little research exists on the innovation behaviour of family firms. Secondly, the study is limited to analyzing Spanish companies, specifically in Murcia, so their results might not be generalizable to companies from other regions or countries. Thirdly, this study treats family firms as a homogeneous category instead of taking into account the differences that exist between various types of family firms.

Several research extensions can be derived from this article. Firstly, future research should also theoretically and empirically study if our findings apply to other types of innovations, for example in (i) Process innovation, (ii) Organizational innovation or (iii) Marketing innovation. 
Secondly, the relationship between entrepreneurial orientation and innovation also could be analysed considering other forms of family involvement, such as in ownership or governance. Similarly, the role of new generations should be considered, as each generation will bring different management styles and objectives to the family firm. Finally, the expansion of the sample to the international arena would allow the generalization of these conclusions.

\section{References}

Aldrich, H. E., and Cliff, J. E. (2003). The pervasive effects of family on entrepreneurship: Toward a family embeddedness perspective. Journal of Business Venturing, 18(5), 507-525.

Ali A, Kalwani M.U, and Kovenock D. (1993). Selecting product development projects: pioneering versus incremental innovation strategies. Management Science, 39(3), 255-274.

Amit, R. and Schoemaker, P. (1993). Strategic assets and organizational rent. Strategic Management Journal, 14, 33-46.

Anderson, P., and Tushman, M. (1990). Technological Discontinuities and Dominant Designs: A Cyclical Model of Technological Change. Administrative Science Quarterly, 35, 604-633.

Aronoff, C. E., and J. L. Ward (1995). Family-Owned Businesses: A Thing of the Past or a Model for the Future? Family Business Review, 8(2), 121-130.

Astrachan, J. H., Klien, S. B., and Smyrnios, K. X. (2002). The F-PEC scale of family influence: A proposal for solving the family business definition problem. Family Business Review, 15(1), 45-58.

Atuahene-Gima, K. (2001). An empirical investigation of the effect of market orientation and entrepreneurship orientation alignment on product innovation. Organization Science, 1(2), 54-74.

Avlonitisa G. J., and Salavoub H. E. (2007). Entrepreneurial orientation of SMEs, product innovativeness, and performance. Journal of Business Research, 60(5), 566-575.

Baker, W. E., and Sinkula, J. M. (2009). The Complementary Effects of Market Orientation and Entrepreneurial Orientation on Profitability in Small Businesses. Journal of Small Business Management, 47, 443-464.

Barney, J., (1991). Firm Resources and Sustained Competitive Advantage. Journal of Management, 17, 99-120.

Bessant, J., Birkinshaw, J., and Delbridge, R. (2004). Innovation as Unusual. Business Strategy Review, 15(3), 32-35.

Bettis R.A., Hitt M.A. (1995). The New Competitive Landscape. Strategic Management Journal, Summer Special Issue, 16, 7-19.

Blundell, R., Griffiths, R., and Van Reenen, J. (1999). Market share, market value and innovation in a panel of British manufacturing firms. Review of Economic Studies, 66(3), 529-554.

Boso, N., Cadogan, J. W., and Story, V. M. (2013). Entrepreneurial orientation and market orientation as drivers of product innovation success: A study of exporters from a developing economy. International Small Business Journal, 31(1), 57-81.
Calantone, R.G., Cavusgil, S.T., and Zhao, Y. (2002). Learning orientation, firm innovation capability and firm performance. Industrial Marketing Management, 31, 515-524.

Casillas, J.C., and Moreno, A.M. (2010). The Relationship between Entrepreneurial Orientation and Growth: The Moderating Role of Family Involvement. Entrepreneurship \& Regional Development, 23, 27-44.

Casillas, J.C., Moreno, A.M., and Barbero, J.L. (2010). A configurational approach of the relationship between entrepreneurial orientation and growth of family firms. Family Business Review, 13(1), 27-44

Chen, H. L., and Hsu, W. T. (2009). Family, Ownership, Board Independence, and R\&D Investment. Family Business Review, 22(4), 347362.

Choi, Y. R., Zahra, S. A., Yoshikawa, T., and Han, B. H. (2015). Family Ownership and R\&D Investment: The Role of Growth Opportunities and Business Group Membership. Journal of Business Research, 68(5), 1053-1061.

Chrisman, J. J., Chua, J. H., and Litz, R. A. (2003). Commentary: A unified perspective of family firm performance: An extension and integration. Journal of Business Venturing, 18(4), 467-472.

Chrisman, J. J., Chua, J. , and Steier, L. P. (2003). An introduction to theories of family business. Journal of Business Venturing, 18(4), 441-448.

Chrisman, J. J., J. H. Chua, and R. A. Litz. (2004). Comparing the agency costs of family and nonfamily firms: Conceptual issues and exploratory evidence. Entrepreneurship Theory and Practice, 28 (4): 335-54.

Classen, N., Carree, M., Van Gils, A., and Petters, B. (2014). Innovation in family and non-family SMEs: an exploratory analysis. Small Business Economics, 42(3), 595-609.

Clausen, T.H., and Pohjola, M. (2013). Persistence of product innovation: comparing breakthrough andincremental product innovation. Technology Analysis \& Strategic Management, 25(4), 369-385.

Craig, B. L., and Moores, K. (2006). A 10-Year Longitudinal Investigation of Strategy, Systems, and Environment on Innovation in Family Firms. Family Business Review 19(1), 1-10.

Covin, J. G., and Slevin, D. P. (1989). Strategic management of small firms in hostile andbenign environments. Strategic Management Journal, 10, 75-87.

Covin, J. G., and Slevin, D. P. (1988). The influence of organization structure on the utility of an entrepreneurial top management style. Journal of Management Studies, 25(3), 217-234.

Covin, J. G., and Slevin, D. P. (1991). A Conceptual Model of Entrepreneurship as Firm Behavior. Entrepreneurship Theory and Practice, 16, 7-25

Covin, J. G., and Wales, W. J. (2018). Crafting HighImpact Entrepreneurial Orientation Research: Some Suggested Guidelines. Entrepreneurship Theory and Practice. Entrepreneurship Theory and Practice, 43(1), 3-18.

Damanpour, F. (1992). Organizational Size and Innovation. Organization Studies, 13(3), 375-402.

Danneels E., and Kleinschmidt E.J. (2001). Product innovativeness from the firm's perspective: its dimensions and their relation with project 
selection and performance. Journal of Product Innovation Management, 18(6), 357-373.

Denison, D. R., A. K. Mishra. (1995). Toward a theory of organizational culture and effectiveness. Organ. Sci, 6(2) 204-223.

De Massis, A., Frattini, F., and Lichtenthaler, U. (2013). Research on Technological Innovation in Family Firms: Present Debates and Future Directions. Family Business Review, 26, 10-31.

Dess, G.G. Y Lumpkin, G.T. (2005). The role of entrepreneurial orientation in stimulating effective corporate entrepreneurship. Academy of Management Executive, 19, 147-156.

Dyer, W. G., JR. (2006). Examining the "family effect" on firm performance. Family Business Review, 19(4), 253-273.

Dyer, B., and Song, M.X. (1998). Innovation strategy and sanctioned conflict: a new edge in innovation? Journal of Product Innovation Management, 15(6), 505-519.

Ferreira, J.J., Azevedo, G.S. and Fernández, R. (2011). Contribution of Resource-Based View and Entrepreneurial Orientation on Small Firm Growth, Cuadernos de Gestión, 11(1), 95-116.

Fernández-Mesa, A., Alegre-Vidal, J., and ChivaGómez, R. (2012). Orientación Emprendedora, Capacidad de Aprendizaje Organizativo y Desempeño Innovador. Journal of technology management and innovation, 7(2), 157-170.

Frishammar, J., and Hörte, S. (2005). Managing External Information in Manufacturing Firms: The Impact on Innovation Performance. Journal of Product Innovation Management, 22(3), 251-266.

Frishammar, J. and Hörte, S. (2007). The role of market orientation and entrepreneurial orientation for new product development performance in manufacturing firms. Technology Analysis \& Strategic Management 19(6): 765-788.

Furtan, W.H., and Sauer, J. (2008). Determinants of food industry performance: survey data and regressions for Denmark. Journal of Agricultural Economics, 59 (3), 555-573.

Galve Gorriz, C., Y Salas Fumas, V. (1996). "Ownership structure and firm performance: Some empirical evidence from Spain", Managerial and Decision Economics, 17, pp.587-594.

Gatingnon H., and Xuereb J. M. (1997). Strategic orientation of the firm and new product performance. Journal of Marketing Research, 34(1), 77-90.

George, B. A., \& Marino, L. (2011). The epistemology of entrepreneurial orientation: conceptual formation, modeling, and operationalization. Entrepreneurship Theory and Practice, 35(5), 9891024.

George, G., Wood, D. R., and Khan, R. (2001). Networking strategy of boards: Implications for small and medium-sized enterprises. Entrepreneurship and Regional Development, 13(3), 269-285.

Gómez-Mejía, L.R., Haynes, K.T., Núñez-Nickel, M., Y Moyano-Fuentes, H. (2007). Socioemotional wealth and business risk in family-controlled firms: Evidence from Spanish olive oil mills. Administrative Science Quarterly, 52, 106-137.

Green, K. M., Covin, J. G., and Slevin, D. P. (2008). Exploring the relationship between strategic reactiveness and entrepreneurial orientation: The role of structure-style fit. Journal of Business Venturing, 23(3), 356-383.

Gudmundson, D., Hartman, E.A., and Tower, C.B. (1999). Strategic orientation: Differences between family and nonfamily firms. Family Business Review, 12(1), 27-39.

Habbershon, T. G., Williams, M., and Macmillan, I. C. (2003). A unified systems perspective of family firm performance. Journal of Business Venturing, 18, 451-465.

Hall, A., Melin, L., and Nordqvist, M. (2001). Entrepreneurship as a radical change in family business: Exploring the role of cultural patterns. Family Business Review, 14, 193-208.

Hall, R. (1992). The strategic analysis of intangible resources. Strategic Management Journal, 13 (1), 135-144.

Hart, S. L. (1992). An integrative framework for strategy-making processes. The Academy of Management Review, 17(2), 327-351.

Hitt, M.A., Ireland, R.D., Camp, S.M., \& Sexton, D.L. (2001). Strategic entrepreneurship: Entrepreneurial strategies for wealth creation. Strategic Management Journal, 22 (special issue), 479-491

Hughes, M., and Morgan, R.E. (2007). Deconstructing the relationship between entrepreneurial orientation and business performance at the embryonic stage of firm growth. Industrial Marketing Management, 36, 651-661.

Hughes, A. (2001). Innovation and business performance: Small entrepreneurial firms in the UK and the EU. New Economy, 8(3), 157-163.

Hurmelinna-Laukkanen, P., Sainio, L. M., and Jauhiainen, T. (2008). Appropriability Regime for Radical and Incremental Innovations, R\&D Management, 38(3), 278-289.

Huybrechts, J., Voordeckers, W., and Lybaert, N. (2013). Risk taking of private family firms: the influence of a nonfamily CEO and the moderating effect of CEO tenure. Family Business Review, 26, 161-179.

Ireland, R. D., Hitt, M. A., and Sirmon, D. G. (2003). A model of strategic entrepreneurship: The construct and its dimensions. Journal of Management, 29(6), 963-989.

Kalantaridis, C., and J. Pheby (1999). Processes of Innovation Among Manufacturing SMEs: The Experience of Bedfordshire. Entrepreneurship and Regional Development, 11(1), 57-78.

Kets de Vries, M. F. R. (1993). The Dynamics of Family Controlled Firms: The Good and the Bad News. Organizational Dynamics, 21(3), 59-71.

Laursen, K., and Salter, A. (2006). Open for innovation: the role of openness in explaining innovation performance among U.K. manufacturing firms. Strategic Management Journal, 27, 131-150.

La Porta, R., F. Lopez-de-Silanes, A. Shleifer, and R. Vishny (1999). Corporate Ownership Around the World. Journal of Finance, 54(2), 471-517.

Le Breton-Miller, I., and Miller, D. (2009). Agency vs Stewardship in Public Family Firms: A Social Embeddedness Reconciliation. Entrepreneurship Theory and Practice, 33(6), 1169-1191.

Link, A.N. (1980). Firm size and efficient entrepreneurial activity: A reformulation of the 
Schumpeter hypothesis. Journal of Political Economy, 88, 771-782.

Lumpkin, G.T., and Dess, G.G. (1996). Clarifying the entrepreneurial orientation construct and linking it to performance. Academy of Management Review, 21(1), 135-172.

Lumpkin, G.T., and Dess, G.G. (2001). Linking two dimensions of entrepreneurial orientation to firm performance: The moderating role of environment industry life cycle. Journal of Business Venturing, 16, 429-451.

Madrid-Guijarro, A., Garcia, D., and Van Auken, H. (2009). Barriers to Innovation among Spanish Manufacturing SMEs. Journal of Small Business Management, 47(4), 465-488.

March, J. G. (1991). Exploration and Exploitation in Organizational Learning. Organization Science, 2, 71-87.

Margaret, M. (2008). The Role of Human Capital and Entrepreneurial Orientation on Radical Product Innovations in Small Scale Carpentry Workshops in Nairobi. Kenyatta University, Kenyatta.

Menguc, B., and Auh, S. (2010). Development and Return on Execution of Product Innovation Capabilities: The Role of Organizational Structure. Industrial Marketing Management, 39(5), 820-831.

Miles, R., Snow, C., Meyer, A., and Coleman, H. (1978). Organizational Strategy, Structure, and Process. The Academy of Management Review, 3(3), 546-562.

Miller, D. (1983). The correlates of entrepreneurship in three types of firms. Management Science, 29, 770-792.

Miller, D., and Friesen, P. H. (1982). Innovation in conservative and entrepreneurial firms: Two models of strategic momentum. Strategic Management Journal, 3, 1-25.

Miller, D., Le Breton-Miller, I., and Lester, R. H. (2011). Family and Lone Founder Ownership and Strategic Behavior: Social Context, Identity, and Institutional Logics. Journal of Management Studies, 48(1), 1-25.

Moreno, A.M., and Casillas, J.C. (2008). Entrepreneurial orientation and growth of SMEs: A causal model. Entrepreneurship Theory and Practice, 32(3), 507-528.

Morris, M.H., and Paul, G.W. (1987). The relationship between entrepreneurship and marketing in established firms. Journal of Business Venturing, 2, 247-59.

Naldi, L., Nordqvist, M., Sjöberg, K., and Wiklund, J. (2007). Entrepreneurial orientation, risk taking, and performance in family firms. Family Business Review, 20, 33-47.

Naman, J.L., and Slevin, D.P. (1993). Entrepreneurship and the concept of fit: A model and empirical tests. Strategic Management Journal, 14, 137-153.

Nasution, H., Mavondo, F., Jekanyika, M., and Oly, N., (2010). Entrepreneurship: Its relationship with market orientation and learning orientation and as antecedents to innovation and customer value. Industrial Marketing Management, 40, 336-345.

Nelson, R.R. (1991). Why do firms differ, and how does it matter? Strategic Management Journal, 12, 61-74.

Neubauer, F., and Lank, A. G. (1998). The family business: Its governance for sustainability. New York: Macmillan.
Newey, L., and Zahra, S. (2009). The evolving firm: How dynamic and operating capabilities interact to enable entrepreneurship. British Journal of Management, 20(1), S81-S100.

Nonaka, I. (1994). A dynamic Theory of Organizational Knowledge Creation. Organization Science, 5, 14-37.

Nordqvist, M., Habbershon, T.G., and Melin, L. (2008). Transgenerational Entrepreneurship: Exploring Entrepreneurial Orientation in Family Firms, In Landström, H., Crijn, H. Laveren, E. \&Smallbone, D., (Eds.) Entrepreneurship, Sustainable Growth and Performance: Frontiers in European Entrepreneurship Research, Northampton, Mass.: Edward Elgar Publishing Limited, 93-116.

Nwachukwv, S., Vitell, S., Gilbert, F., and Barnes, J. (1997). Ethics and social responsibility in marketing: an examination of the ethics evaluation of advertising strategies. Journal of Business Research, 39(2), 107-118.

O'Regan, N., and Sims, M. (2008). Identifying high technology small firms: A sectoral analysis. Technovation, 28, 408-423.

OECD, and Eurostat. (2005). Oslo manual: Guidelines for collecting and interpreting innovation data (3rd ed.). Paris: Organisation for Economic Cooperation and Development, Statistical Office of the European Communities.

Poazi, F., Tamunosiki-Amadi, J., Fems, M. (2017). The Resource-Base View of Organization and Innovation: Recognition of Significant Relationship in an Organization. World Academy of Science, Engineering and Technology, Open Science Index 123, International Journal of Economics and Management Engineering, 11(3), 697 - 704.

Podsakoff, P.M., and Organ, D.W. (1986). Selfreports in organizational research: problems and prospects. Journal of Management, 12(4), 531-544.

Rauch, A., Wiklund, J., Frese, M., and Lumpkin, G.T. (2009). Entrepreneurial orientation and business performance: An assessment of past research and suggestions for the future. Entrepreneurship Theory and Practice, 33, 761781.

Runyan, R., Huddleston, P. and Swinney, J. (2006). Entrepreneurial orientation and social capital as small firm strategies: a study of gender differences from a Resource-Based View. Entrepreneurship Management, (2), 455-477

Salavou, H., and Avlonitis, G. (2008). Product innovativiness and performance: a focus on SMEs. Management Decision, 46 (7), 969-985.

Salavou, H. and Lioukas, S. (2003). Radical Product Innovations in SMEs: The Dominance of Entrepreneurial Orientation. Creativity and Innovation Management, 12, 94-108.

Salvato, C. (2004). Predictors of entrepreneurship in family firms. Journal of Private Equity, 27(3), 6876.

Schumpeter, J.A. (1934). The Theory of Economic Development. Cambridge, Massachusetts: Harvard University Press.

Sharma, P. (2004). An Overview of the Field of Family Business Studies: Current Status and Directions for the Future. Family Business Review, 17(1), 1-36.

Sharma, P., Chrisman, J. J., and Chua, J. H. (1997). Strategic Management of the Family Business: Past 
Research and Future Challenges. Family Business Review 10, 1-36.

Simpson, P.M., Sigaw, J.A., and Enz, C.A. (2006). Innovation orientation outcomes: the good and the bad. Journal of Business Research, 59, 1133-1141.

Sirmon, D. G., Arrègle, J. L., Hitt, M. A., and Webb J. W. (2008). The Role of Family Influence in Firms' Strategic Responses to Threat of Imitation. Entrepreneurship Theory and Practice 32(6), 979998.

Sirmon, D.G., and Hitt, M.A. (2003). Managing resources: Linking unique resources, management, and wealth creation in family firms. Entrepreneurship Theory and Practice, 27, 339358.

Smart, D.T., and Conant, J.S.(1994). Entrepreneurial orientation, distinctive marketing competencies and organizational performance. Journal of Applied Business Research, 10, 28-38.

Sorescu, A., and Spanjol, J. (2008). Innovation's Effect on Firm Value and Risk: Insights from Consumer Packaged Goods. Journal of Marketing, 72, 114-132.

Souitaris, V. (2003), Determinants of technological innovation. Current research trends and future prospects in Shavinina, L (ed.), International Handbook on Innovation, Pergamon, 513-528.

Stam. W., Elfring, T. (2008). Entrepreneurial Orientation and New Venture Performance; The moderationg role of Intra - and Extra - Industry Social Capital. Academy of Management Journal, 51, 97-111.

Steier, L. (2007). New venture creation and organization: A familial sub-narrative. Journal of Business Research, 60, 1099-1107.

Steier, L. (2009). Where Do New Firms Come From? Households, Family Capital, Ethnicity, and the Welfare Mix. Family Business Review, 22 (3), 273278.

Teece, D.J. (2007). Explicating dynamic capabilities: The nature and microfoundations of (sustainable) enterprise performance. Strategic Management Journal, 28, 1319-1350.

Van Gils, A. (2005). Management and governance in Dutch SMEs. European Management Journal, 23(5), 583-589.

Vandekerkhof, P., Steijvers, T., Hendriks, W., and Voordeckers, W. (2015). The Effect of Organizational Characteristics on the Appointment of Nonfamily Managers in Private Family Firms: The Moderating Role of Socioemotional Wealth. Family Business Review, 28(2), 104-122.

Villalonga, B., and Amit, R. (2006). How do family ownership, control and management affect firm value? Journal of Financial Economics, 80(2), 385417.

Wales, W. J., Gupta, V. K., and Mousa, F.-T. (2013). Empirical research on entrepreneurial orientation: An assessment and suggestions for future research. International Small Business Journal, 31(4), 357383.

Ward, J. L. (1997). Growing the family business: Special challenges and best practices. Family Business Review, 10, 323-337.

Westhead, P., and Howorth, C. (2007). Types of private family firms: An exploratory conceptual and empirical analysis. Entrepreneurship and Regional Development, 19, 405-431.

Wiklund, J., and Shepherd, D. (2005). Entrepreneurial orientation and small business performance: a configurational approach. Journal of Business Venturing, 20, 71-91.

Workman J. P. (1993). Marketing's limited role in new product development in one computer systems firm. Journal of Marketing Research, 30, 405-421.

Zahra, S. A. (2005). Entrepreneurial risk taking in family firms. Family Business Review, 18, 23-40.

Zahra, S. A., Hayton, J. C., and Salvato, C. (2004). Entrepreneurship in family vs. non-family firms: A resource-based analysis of the effect of organizational culture. Entrepreneurship Theory and Practice, 28(4), 363-381.

Zhou K. Z., Yim C. K., and Tse D. K. (2005). The effects of strategic orientations on technology and market-based breakthrough innovations. Journal of Marketing, 69(4), 42-60. 